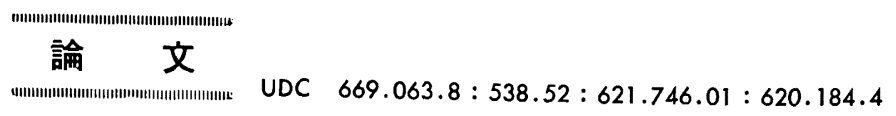

\title{
凝固組織に及ぼす電磁気力の効果*
}

\author{
浅井 滋生 ${ }^{* *} \cdot$ 安井 研二***.鞭䉷**
}

\section{Effects of Electric and Magnetic Forces on the Solidified Structure}

\author{
Shigeo AsaI, Kenzi YASUI, and Iwao Muchi
}

\begin{abstract}
Synopsis:
To clarify the effects of the electric and magnetic forces on the solidified structure, the solidification experiments were systematically conducted on the $\mathrm{Sn}-10 \% \mathrm{~Pb}$ alloy. A direct or an alternative electric currents, magnetic currents and the currents combined them were introduced into the molten metal. The alloy was solidified under the nine different conditions.

The effects of the electric field, the magnetic field and the combined field on each solidified structure were examined on the basis of the solidified structure and the theoretical considerations of the fluid flow caused under each experimental condition.

It is concluded that the columnar structure can be developed by preventing the fluid flow and the fine equi-axed zone can be obtained by the forced fluid flow.
\end{abstract}

\section{1. 緒言}

電磁気力を応用した製鋼プラントには，磁界の変化に 基づいて溶鋼の流動を誘起させるものとして，溶鋼プー ルを電磁掜拌する連鋳機, ASEA-SKF 装置, 志なしの 誘導炉(coreless induction furnace)がある。また，ESR 装置では，熱源として直接メタルに印加される電流によ つて流動で誘起される.電磁気力が㠜固組織に及ぼす効 果については, 彷来, 直流磁束を使用すると溶融金属の 自然対流が 抑制されて柱状晶の発達が助長されること 1) 3), 移動磁束による電磁誘導掜拌方式では溶融金属の 流動が引き起こされて等軸晶率が增加すること4) 9)，ま た，直流電流と直流磁束を同時に作用させると㠜固組織

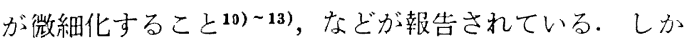
し, 直流あるいは交流の電流と直流あるいは交流の磁束 を単独に，あるいは，併用して作用させる場合に，溶融 金属中に誘発される電磁気力が㠜固組織に及ぼす効果に ついて定量的かつ系統的に調べた報告は見当らない．

本研究では，凝固組織に及ぼす電磁気力の効果を定量 的に解明するために, 電流と磁束を単独あるいは垪用す る各場合について, 系統的に一連の凝固実験を行ない, その際誘起される電磁気力や流速分布を理諭的に解析
し，さらに，これらの結果に基づいて，工業的に有用と 思われる電磁㩭拌条件について検討する.

\section{2. 実 験 方 法}

実験は Table 1 に示すように, 電流については, 電 流を作用させない場合，直流電流を作用させる場合，交 流電流を作用させる場合の 3 種類，また，磁束について は，磁束を作用させない場合，直流磁束*を作用させる 場合，交流磁束**を作用させる場合の 3 種類をそれぞ れ組合せて得られる合計 9 種類の条件下で実験を行なつ た. Table 1 に記入した番号は, それでれ，行と列によ つて決められる電流と磁束の条件における実験走示すも のである.

Case I は，他の Case と比較するための基準試料を 作る実䮖である. Case $\mathbb{I} 〜$ VI と Case VII IX では，異 なる実験装置を使用したので，Case I の実験はそれぞ れの装置で別個に行なつた，前者の実験装置の平面図を Fig. 1 に示す. 片側に冷却榑を設置した鋳型 $(80 \times 50 \times$ $20 \mathrm{~mm}$ ，長辺側の壁および底面は厚さ $8 \mathrm{~mm}$ の耐火材,

* たとえば，永久磁石の磁束のように，時間的に磁束の大きさおよび その方向が変化しないもので，直流煞流をソレノイドに流した場台 に発生する磁束である.

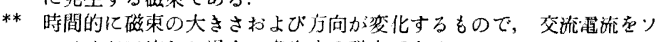
レノイドに流した場合に発生する磁束である。

$*$ 昭和 51 年 10 月本会講演大会にて発表 昭和52年 3 月 8 日受付 (Received Mar. 8，1977)

** 名古屋大学工学部 工博 (Department of Iron \& Steel Engineering, Nagoya University, Furo-cho Chikusa-ku Nagoya 464)

*** 名古屋大学工学部 (Department of Iron \& Steel Engineering, Nagoya University) 
Table 1. Case numbers giving the experimental conditions.

\begin{tabular}{|c|c|c|c|}
\hline $\begin{array}{c}\text { Electric } \\
\text { current } \\
\text { Magnetic } \\
\text { curren t } \\
\end{array}$ & $I=0$ & $\begin{array}{l}I=I_{0} \\
(\mathrm{DC})\end{array}$ & $\begin{array}{c}I=I_{0} \sin \omega t \\
\quad(\mathrm{AC})\end{array}$ \\
\hline$\Phi=0$ & I & II & III \\
\hline $\begin{array}{l}\Phi=\Phi_{0} \\
(\mathrm{DC})\end{array}$ & IV & $\mathrm{V}$ & VI \\
\hline $\begin{array}{c}\Phi=\Phi_{0} \sin \omega t \\
(\mathrm{AC})\end{array}$ & VII & VIII & IX \\
\hline
\end{tabular}

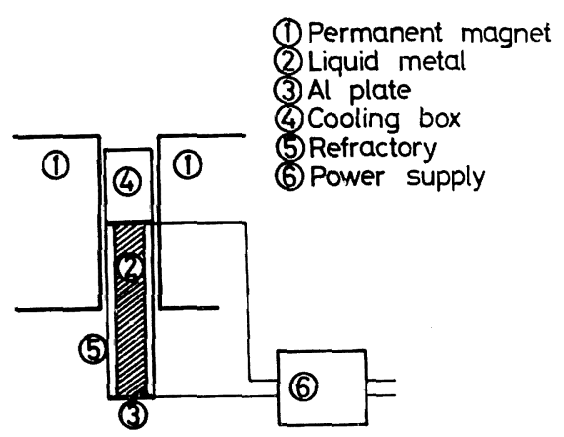

Fig. 1. Schematic experimental apparatus for solidifying under the direct magnetic field.

短辺側の壁は厚さ $1 \mathrm{~mm}$ のアルミ板を使用）を作製し， 鋳型内の溶融金属を一方向凝固させた。磁束密度として 約 0.4 テスラの永久磁石を使用し，鋳型の長辺の半分が 磁極間に入り，長辺側が磁束と直交するように設置し た. 電流は鋳型短辺側の各アルミ板を電極上して，直流 および交流の電源に接続し，溶湯中に 2 70A の通電を 行なつた．各実験とも， $300^{\circ} \mathrm{C}$ に加熱した $\mathrm{Sn}-10 \% \mathrm{~Pb}$ の溶融金属試料を鋳型入注入し，浲却槽を通る水の流速 を調節して一定の冷却条件に保つた。

交流磁束を作用させる場合（Case UII $\mathbb{X}$ ) の実騟装固 の正面図を Fig. 2 に示す. 円筒状のルツボ内（内径7 $\mathrm{cm}$, 高さ $10 \mathrm{~cm}$ ) で $300^{\circ} \mathrm{C}$ に加熱した $\mathrm{Sn}-10 \% \mathrm{~Pb}$ の 溶融金属試料をルツボごと泠却榑の上に設置して底面か ら一方向凝固させた，通電の際には，約 $1.5 \mathrm{~cm}$ の間腺 に固定された 2 本の銅棒をメタル中に浸し，直流および 交流の電源に接続し, 溶湯中に $10 \mathrm{~A}$ の通電を行なつた.

\section{3. 理 論 解 析}

\section{1 電磁気力の誘導}

電流および磁束によつて溶融金属中に誘起される体積 力は, (1)〜 (3)式に示す Maxwell の方程式と(4)式 に示す Ohm の式を適用して（5）式から得られる.

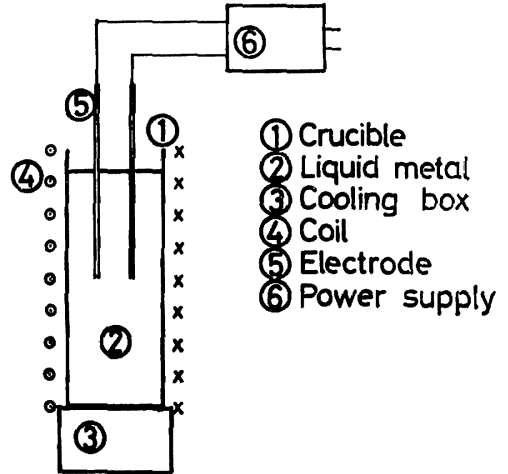

Fig. 2. Schematic experimental apparatus for solidifying under the alternating magnetic field.

$$
\begin{aligned}
& \nabla \times \mathbf{E}=-\mu(\partial \mathbf{H} / \partial t) \\
& \nabla \times \mathbf{H}=\mathbf{i} \quad \ldots \ldots \ldots \ldots \ldots \ldots \ldots \\
& \nabla \cdot \mathbf{H}=0 \quad \ldots \ldots \ldots \ldots \ldots \\
& \mathbf{i}=\sigma(\mathbf{E}+\mu \mathbf{V} \times \mathbf{H}) \ldots \ldots \\
& \mathbf{F}=\mu \mathbf{i} \times \mathbf{H}=\mathbf{i} \times \mathbf{B} \ldots \ldots
\end{aligned}
$$

交流の電流や磁束を作用させる場合には, 時間的に大 きさが変化するような体積力が媒体中に誘起される. そ の場合には，体積力を变化の一周期にわたつて平均化し て（6）式で表わす.

$$
\overline{\mathbf{F}}=\frac{1}{\mathrm{~T}} \int_{0}^{T} \mathbf{F} d t
$$

ここで，周期は， $T=2 \pi / \omega$ で表わされる。また，系内 で体積力が分布している場合には，系の全空間における 平均の体積力 $\mathbf{F}_{m}$ は，（7）式で示される.

$$
\mathbf{F}_{m}=\frac{1}{v} \iiint \mathbf{F} d v
$$

次に, Table 1 に示した Case $\mathbb{I} \sim \mathbb{X}$ の実験条件の各場 合について，溶融金属中に誘発される体積力を求好。

Case II（直流電流だけを作用させる場合）

解析上の取扱いを簡単にするため, 試料形状を半径 $a$ の円筒形とする. 電流を円筒の軸方向に流すものとする と, 電流密度は $(8)$ 式で与えられる

$$
i_{Z}=\left(I / \pi a^{2}\right)
$$

誘導磁界は円周方向に生じ, その大きさはアンペアの 周回路の法則を使つて（9) 式で示される.

$$
H_{\theta}=\left(I / 2 \pi a^{2}\right)(a-X) \cdots
$$

ただし， $X$ は円筒表面から中心に向かつての半径方向距 離である。（8)式と（9）式を（5）式に代入すると， この場合には，体積力が半径方向に生じ，および，その 大きさは（10）式で与えられることがわかる。

$$
F_{X}=-\mu i_{Z} H_{\theta}=-\frac{\mu}{2}\left(I / \pi a^{2}\right)^{2}(a-x)
$$




$$
=-\frac{\mu}{2} i_{Z}^{2}(a-X)
$$

(10) 式を（7）式に代入すると, 試料全体にわたつて平 均化した体積力 $F_{X}, m$ が (11) 式のように得られる。

$$
F_{X}, m=-\frac{\mu}{6} i^{2} a=-\frac{\mu}{6} I^{2} / \pi^{2} a^{3}
$$

\section{Case III（交流電流だけを作用させる場合）}

交流電流が導体中を流れる場合には, 電流密度および 誘導磁束密度はともに, 導体の表面で高く, 内部に向か つて急激に減少する表皮効果 (skin effect) が生ずるた めに，この表皮の厚さに比べて試料が十分大きければ， 一次元問題としての取报いが可能となる.この場合, 電 流密度分布を求好基礎式は，(1)〜 (3) 式と(4)式の 右辺括弧内の第 2 項を省略*した式から導出され，(12) 式で示される.

$$
\partial^{2} i_{Z} / \partial X^{2}=\mu \sigma\left(\partial i_{Z} / \partial t\right)
$$

境界条件 (13) 式のもとで (12) 式を解くと, (14) 式に示 すような解が得られる。

$$
\begin{aligned}
& X=\infty \text { で } i_{Z}=0, X=0 \text { で } i_{Z}=i_{Z}, o^{e^{j \omega t}} \ldots \\
& i_{Z}(X)=i_{Z}, o^{-r X j} \quad e^{j \omega t} \ldots \ldots \ldots \ldots \ldots \ldots \ldots \ldots
\end{aligned}
$$

ただし， $\gamma=\sqrt{-\mu \sigma \omega j}$ である。

(2)式と(14)式から, 誘導磁界が次のように得られる.

$$
\begin{aligned}
H_{Y} & =\int_{X}^{\left(b_{2} / 2\right)} i_{Z}(X) d X \\
& =(-1 / \gamma j) i_{Z}, o\left(e^{-r b_{2} j / 2}-e^{-\gamma} X^{j}\right) e^{j \omega t} \ldots
\end{aligned}
$$

(14)式と（15) 式を（5) 式に代入し, さらに，(6)式と (7)式に従つて, 時間的および空間的に平均化した体積 力を求めると(16)式が得られる

$$
\begin{aligned}
& \bar{F}_{X}, m=\left(\mu i_{Z, o}^{2} / 4 \beta^{2} b_{2}\right) \cdot\left(-e^{-\beta b_{2}}\right. \\
& \left.+2 \cos \left(\beta b_{2} / 2\right) \cdot e^{-\beta b_{2} / 2}-1\right) \cdots \cdots \\
& \text { ただし }, \quad \beta=\sqrt{\mu \sigma \omega / 2} \text { である. }
\end{aligned}
$$

なお，(16) 式中の $i_{Z}, o$ は次のように求められる.す なわち, 実験試料断面は矩形であり, その長辺と短辺の 長さをそれぞれ $b_{1}, b_{2}$ とし，表皮勃果が作用すること を考虑すると, $i_{Z}, o$ と供給電流 $I$ との間には近似的に (17)式のような関係が得られる.

$$
\sqrt{2} \mathrm{I}=2 b_{1} i_{Z}, O \cdot \int_{0}^{b}{ }^{2 / 2} \operatorname{Re}\left\{e^{-\gamma X j}\right\} d X . .
$$

ここで, $\operatorname{Re}\{\}$ は, \{ \} 内の実数部を取ることを意 味する。

（17）式の積分を実行して $i_{Z}, o$ を求めると，(18)式のよ うになる。

$$
\begin{aligned}
i_{Z}, o & =\sqrt{2} \beta I /\left[\left\{1+e^{-\beta b_{2} / 2}\left(-\cos \left(\beta b_{2} / 2\right)\right.\right.\right. \\
& \left.\left.+\sin \left(\beta b_{2} / 2\right),\right\} \cdot b_{1}\right] \cdots \cdots \ldots \ldots \ldots \ldots \ldots \ldots \ldots \ldots \ldots \ldots \ldots \ldots \ldots
\end{aligned}
$$

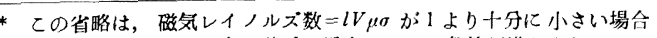
に許されるもので，本実驗系の場合にはこの条件が满たされる。

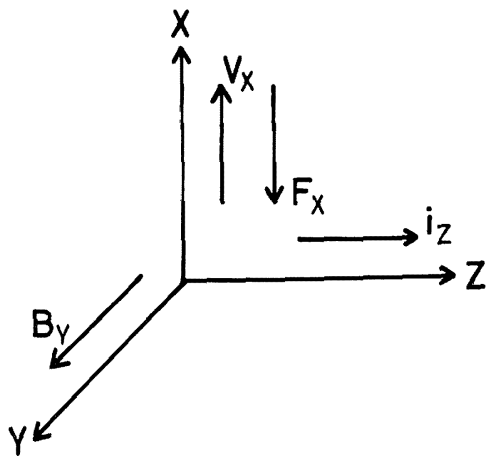

Fig. 3. Schematic representation of the relation between $V_{X}, B_{Y}, i_{Z}$ and $F_{X}$.

Case IV（直流磁束だけを作用させる場合）

Fig. 3 に示すように, $Y$ 方向の直流磁束 $B_{Y}$ の作用 下にある媒体に何らかの原因(自然対流や凝固収縮など) で $X$ 方向の流速 $V_{X}$ が存在すると誘導電流が生ずるが, これは(4)式から求められる。この場合には，(4)式は (19)式で表わされる.

$$
i_{Z}=\sigma \mu V_{X} H_{Y}
$$

この誘導電流と采に作用している磁束 $B_{Y}$ によつて, 体 積力 $F_{X}$ が䄧起されるが，それは (5) 式から求められ る.この場合には，(5)式は(20)式で示される.

$$
F_{X}=-\sigma \mu^{2} V_{X} H_{Y}^{2}
$$

(20)式から明らかなように, この体積力は常に流速 $V_{X}$ と逆向きに作用し，その大きさは流速に比例することが わかる，Z方向に流動が生ずる場合にも同様な取扱いが 可能であるから，直流磁束は，溶融金属中に生ずる磁束 方向以外の方向の流動を抑制するように作用することが わかる。

Case V（直流電流と直流磁束を併用する場合）

実験条件に従つて, 直流電流 $i_{Z}$ と直流磁束 $B_{Y}$ を直 交させる場合に生ずる体積力は，（5）式から得られる が，この場合には (21) 式で示される.

$$
F_{X}=-\mu i_{Z} H_{Y}
$$

Case VI（交流電流と直流磁束を併用する場合）

交流電流によつて媒体中に生ずる誘導交流磁束が，系 に作用している直流磁束に比べて十分小さいと仮定（本 実験条件下ではこの仮定が成り立つ）し， Case N と同 様に采内で流速 $V_{X}$ が存在すると仮定すれば，電流密 度 $i_{Z}$ は(14)式と(19)式から，(22)式のように表わされ る.

$$
i_{Z}=i_{Z}, o e^{-\gamma X j} e^{j \omega t}+\sigma \mu V_{X} H_{Y}
$$

系に作用している磁束 $B_{Y}$ と(22) 式の $i_{Z}$ 安 (5) 式に 
代入して，系に誘起される体積力を求めると，(23)式の ようになる。

$$
F_{X}=-\mu i_{Z},{ }_{o} H_{Y} e^{-\beta X} \sin (\omega t-\beta X)-\sigma \mu^{2} V_{X} H_{Y}^{2} \cdots
$$

(23)式は時間的に変化する瞬間的な体積力を表わしてい るが，(23)式を（6)式に代入すれば，時間的に平均化し た体積力が，(24)式のように表わされる。

$$
\bar{F}_{X}=-\sigma \mu^{2} V_{X} H_{Y}^{\prime}
$$

(23)式の右辺第 1 項で示されるように, 溶融金属中に大 きな体積力が瞬間的に誘起されているが，その方向が時 間的に変化するため，時間的に平均化すると(23) 式の右 辺第 1 項が消失し (24) 式は Case N $の(20)$ 式と一致寸 ることになる. 60 サイクルという速い変化を伴う場合 には, 流体の力学的な緩和時間 $t=\rho l^{2} / 2 \pi \mu f$ に比べて, 変化が十分に速いため，流体はマクロスケールではその 変化に追従できなくなる. その結果, 実質的に流体のマ クロな運動を規定するものは, 瞬間的体積力（(23)式） ではなく，時間的に平均化された体積力（(24)式）とな る.そのため，ほぼ同一の供給エネルギー条件のもとで Case IV と Case VI の実験を行なうことによつて，金属 の凝固現象が流体のマクロな運動の影響を受けやすい か，あるいは，ミクロな振動の影響を受けやすいかにつ いて推察できると考えられる.

Case 杖（交流磁苯だけを作用させる場合）

Case III と同様:二，この場合にも表皮効果を考虑して， 問題を簡単化して一次元問題として取报う. Case III の (12)式の導出と同様にして，(25)式が得られる.

$$
\partial^{2} H_{Z} / \partial X^{2}=\mu \sigma\left(\partial H_{Z} / \partial t\right)
$$

境界条件(26)式のもとで(25)式を解くと，(27)式のよう に解が得られる。

$$
\begin{aligned}
& X=\infty \text { で } H_{Z}=0, X=0 \text { で } H_{Z}=H_{Z}, o^{e^{j \omega l} \ldots} \\
& H_{Z}(X) \fallingdotseq H_{Z}, o^{-r X j} \quad e^{j \omega t} \quad \ldots \ldots \ldots \ldots \ldots \ldots \ldots
\end{aligned}
$$

(27)式を(2)式に代入すると， $i_{Y}(X)$ が(28)式のように 表わされる。

$$
i_{Y}(X)=-j \gamma H_{Z}, o^{-\gamma X j} e^{j \omega !}
$$

(27) 式と(28) 式の実数部を( 5 ) 式に代入することによつ て体䅡力 $F_{X}$ が求められるが，てれを(6) 式に代入し て整理すると, 時間的に平均化した体積力 $\bar{F} X$ が (29) 式のように得られる.

$$
\bar{F}_{X}=-\mu(\beta / 2) H_{Z}^{2}, o e^{-2 \beta X}
$$

(29)式をさらに(7)式に代入して, 系全体にわたつて平 均化した体稓力 $F_{X}, m$ 安求めると，(30)式のようにな る.

$$
\bar{F}_{X}, m=-\mu H_{Z}^{2},{ }_{o}\left(1-e^{-2 \beta a}\right) / 4 a \cdot
$$

Case VIII（直流電流と交流磁束を併用する場合）

媒体中に印加した直流電流と交流磁束によつて，それ
ぞれ誘起される誘導磁束と誘導電流が，印加した磁束や 電流に比べて十分小さいとして無視することができる場 合には，印加した直流電流密度 $i_{Y}$ と Case II と同様に して導出される印加した磁束密度分布 $B_{Z}(X)=\mu H_{Z}, o$ $e^{-r X j} e^{j \omega l}$ をそれでれ，（5）式に代入して体積力を求 めると(31)式が得られる.

$$
F_{X}=-\mu i_{Y} H_{Z}, o^{-\beta X} \cos (\omega t-\beta X)
$$

(31)式を(6)式に代入して, 時間的平均值 $\bar{F} X$ を求め ると(32)式となる.

$$
\bar{F}_{X}=0
$$

すなわち, Case VI の場合と同様に，瞬間的には体積力 が存在するが，流体通動を引き起こす体皘力は存在しな いことになる。

なお，誘導磁束と誘導電流を無視しない場合について は, Case II と Case VII に示した誘導と同様にして, 近 似的に，体積力の時間的および空間的な平均值が(33)式 のように表わされる.

$$
\begin{aligned}
\bar{F}_{X}, m & =-(\mu / 6) I^{2} /\left(\pi^{2} a^{3}\right) \\
& -\mu H_{Z}^{2},{ }_{o}\left(1-e^{-2 \beta a}\right) / 4 a
\end{aligned}
$$

Case IX（交流電流と交流磁束を併用する場合）

Case VII と同様に, 誘導電流と誘導磁束を無視し， Case VII に示した誘導と同様にして, 交流磁束密度分布 を求め, 次に, 電極棒から印加する電流密度が $i_{Y}, O \cos$ $\omega t$ で表わされるとして, 電流密度と磁束密度を $(5)$ 式 に代入すると(34)式が得られる.

$$
F_{X}=\mu H_{Z}, o i_{Y}, o e^{-\beta X} \cos (\omega t-\beta X) \cos \omega t \cdots
$$

(34)式を(6) 式に代入して, 時間平均の体積力を求める 上(35)式が得られる.

$$
\bar{F}_{X}=\mu H_{Z}, o i_{Y}, o e^{-\beta X} \cos \beta X / 2
$$

(35)式を(7)式に代入して, 空間的な平均值を求めると (36)式が得られる.

$$
\begin{aligned}
\bar{F}_{X}, m & =\mu H_{Z}, o i_{Y}, o \\
& \times\{e-\beta a(-\cos \beta a+\sin \beta a)+1\} / 4 a \beta \cdots
\end{aligned}
$$

ここで，電流密度 $i_{Y}, O$ は，供給電流を電極棒浸皘面積 で割つて求められる.

\section{2 供給エネルギー}

系に加えられた電気エネルギー $W$ は，(37) 式で表わ される。

$$
W=R I^{2} t=V I t
$$

ここで， $R$ は電気抵抗であり，電気伝導度 $\sigma$ との間に は(38)式の関係がある.

$$
R=(1 / \sigma) \cdot(l / s)
$$

また，磁界が存在している場における磁気エネルギー は，(39)式で示される.

$$
W=(1 / 2) L I^{2}
$$


Table 2. Supplied electric current density and supplied magnetic current density.

\begin{tabular}{|c|c|c|c|}
\hline$(T) \quad\left(\mathrm{A} / \mathrm{m}^{2}\right)$ & $i=0$ & $i=i_{0}$ & $i=i_{0} \sin \omega t$ \\
\hline$B=0$ & $\begin{array}{l}0 \\
0\end{array}$ & $\begin{array}{c}8.75 \times 10^{4} \\
0\end{array}$ & $\begin{array}{c}6.75 \times 10^{4} \\
0\end{array}$ \\
\hline$B=B_{0}$ & $\begin{array}{c}0 \\
0.4\end{array}$ & $\begin{array}{l}2.5 \times 10^{3} \\
0.4\end{array}$ & $\begin{array}{c}1.17 \times 10^{4} \\
0.4\end{array}$ \\
\hline$B=B_{0} \sin \omega t$ & $\begin{array}{c}0 \\
0.016\end{array}$ & $\begin{array}{c}1.25 \times 10^{4} \\
0.016\end{array}$ & $\begin{array}{c}1.25 \times 10^{4} \\
0.016\end{array}$ \\
\hline
\end{tabular}

Table 3. Mean values of body force and supplied electric and magnetic energy.

\begin{tabular}{|c|c|c|c|}
\hline 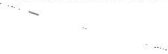 & $i=0$ & $i=i_{0}$ & $i=i_{0} \sin \omega t$ \\
\hline$B=0$ & $\begin{array}{l}0 \\
0\end{array}$ & $\begin{array}{c}25.4\left(\mathrm{~N} / \mathrm{m}^{3}\right) \\
14(\mathrm{~J})\end{array}$ & $\begin{array}{c}29.0 \\
8.33\end{array}$ \\
\hline$B=B_{0}$ & $\begin{array}{r}3360 \\
2.55\end{array}$ & $\begin{array}{r}1000 \\
2.57\end{array}$ & $\begin{array}{r}3360 \\
3.04\end{array}$ \\
\hline$B=B_{0} \sin \omega t$ & $\begin{array}{r}3.75 \\
0.378\end{array}$ & $\begin{array}{r}4.02 \\
0.663\end{array}$ & $\begin{array}{r}50.0 \\
0.663\end{array}$ \\
\hline
\end{tabular}

ここで，Lはインダタタンスであり，(40)式で表わされ ๖.

$$
L=\lambda \mu \pi a^{2} N^{2} / l \quad[\mathrm{H}]
$$

なお，磁界の場以打ける単位体積当たりの磁気エネルギ 一は，(41)式でも表わされる.

$$
w=(1 / 2) H B=(1 / 2) \mu H^{2} \quad\left[\mathrm{~J} / \mathrm{m}^{3}\right]
$$

(41)式を系全体にわたつて積分すると, 系を磁界の場に 置くために必要となる磁気エネルギーが求められる.

Table 2 に, 各実験で使用した電流密度と磁束密度の数 值を示す. Table 3 には, Case I から Case IX の各場 合について，系内に誘起される体䅡力の時間的·空間的 平均値の絶対値, 実験で系に供給した電気的および磁気 的なエネルギーの数值を, Table 2 の実験条件に基づい て計算して示した.な打，試料を円筒形々近似して解析 した Caseについては，実験系と同じ断面起持つ円筒々 してその半径を見積もり，Case IV とVでは解析で求め た体積力表現に流速が入るが，ここでは流速它約 $1 \mathrm{~cm} /$ sec として計算した．また，Case VII〜 XX の場合には， 大部分の磁束は試料とコイルの間友通り, 試料に作用し ないことが考兑られるが, Table 3 の数值は，試料定通 る有効磁束をンレノイド断面平均磁束の $1 / 20^{*}$ として 求めたものである。

* ソレノイト端の直流磁束の則定值から概算した値である.

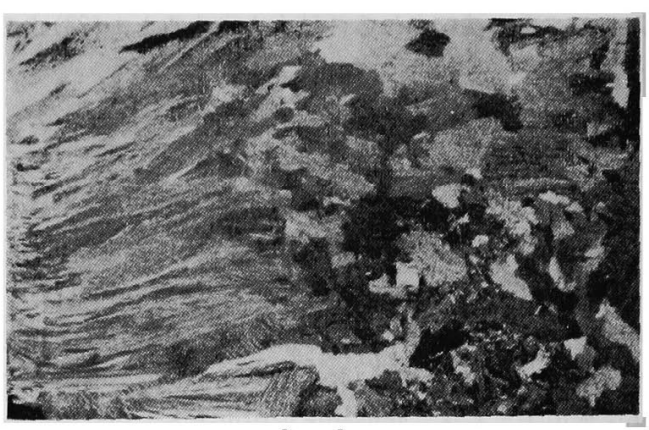

Case I

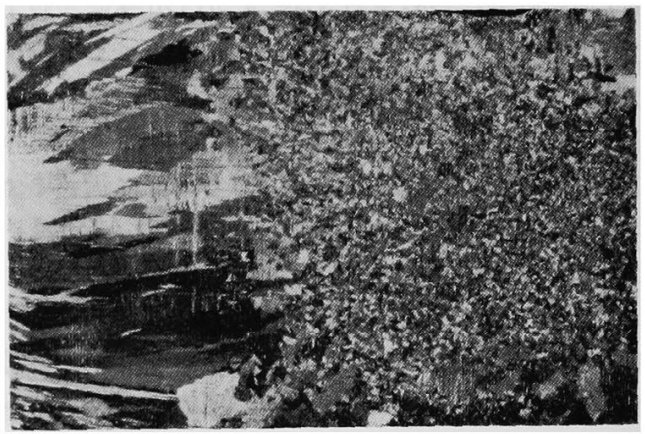

Case I

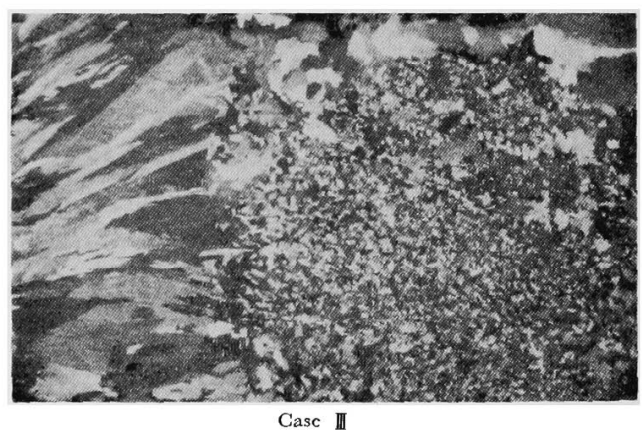

Photo. 1. Macrostructure of case I, II and III . Magnification 0.8 times.

\section{4. 実験結果亡考察}

Photo. 1 は Case I， II， III の各実験で得られたマ ク口組織である.電流も磁束も作用させない場合のCiase I 存標準試料として，Case II と Case III を比較する と，それぞれ，微細化した組織になつていることがわか る. Table 2 に示すように, Case II と Case III では, ともに印加した電流の密度が大きいために, 印加電流と 誘導磁束との作用によつて，(11)式抢よび(16)式に示し たような体積力が溶融金属試料中に誘起され，この体皘 力によつて溶融金属が流動した結果, その組織が微細化 したものと考えられる.しかし，この体積力は，印加電 


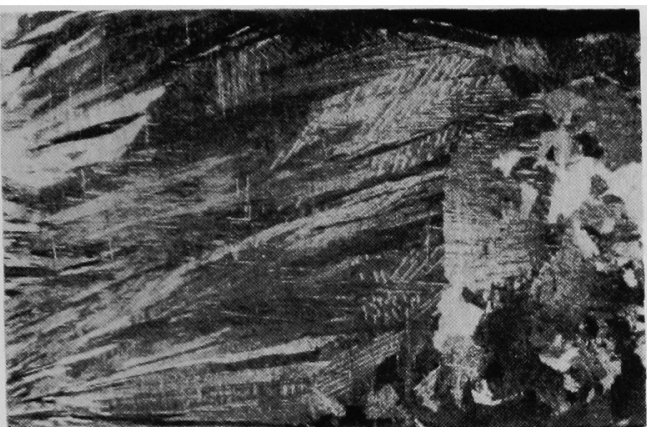

Case IV

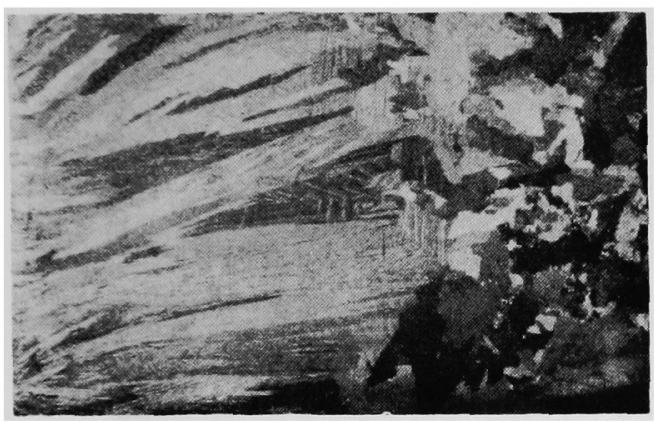

Case VI

Photo. 2. Macrostructure of case IV and VI. Magnification 0.8 times.

流とそれによる誘導磁束との作用によつて間接的に誘起 されたものであり， Table 3 に示したように，体積力の 值はあまり大きくないので, 大きな印加電流の割には, 微細化の程度は顕著ではない。

Photo. 2 は, Case IV と VI の各実験で得られだマ クロ組織である. 理論解析で示したように, Case $\mathbb{N}$ と Иの場合には，(20) 式あるいは（24）式に基づいて流動 を抑制する力が働くために，系内で起こる自然対流が抑 制され, その結果, Photo. 1 に示した Case I の凝固 組織と比較して, 両者とも柱状晶の占为る割合が增加し たものと考えられる。

Case VI の場合には，理諭解析で示した結果から推察 すると, 溶融金属試料中に 60 サイクルの微小振動が生 じていると考光られるが，その㠜固組織が Case IV の それとほとえど変わらないことから，本実験条件下では 金属の㠜固現象は流体運動とそれに伴つて生ずる温度分 布によつて支配されたと推察される.

Case V の場合には, Photo. 1 に示したCase I の㠜 固組織と比較して，明らかに組織が微細化していること がわかる，この場合，流速分布と凝固組織の関係を見る ために $2 \mathrm{~A}$ と $10 \mathrm{~A}$ の電流（電流密度はそれぞれ，2.5 $\left.\times 10^{3} \mathrm{~A} / \mathrm{m}^{2}, 12.5 \times 10^{3} \mathrm{~A} / \mathrm{m}^{2}\right)$ を印加した場合の㠜固組
織と流速分布を Photo. 3 に示した. Case V の場合, Table 2 に示したように印加した電流と磁束によつて直 接的に大きな体積力が系に誘起されるために，激しい流 動が引き起こされて, 組織が大幅に微細化したものと考 えられる。なお，この場合の流速分布は，(21)式に基ゔ く体積力を Navier-Stokes 式の外力項に代入して, 数 值計算*によつて求めたものである ${ }^{14)}$ ，流速分布注凝固 の進行に伴つて変化するが，上段の流速分布は，凝固開 始前の状態であり，鋳型内の溶湯全体が流動している場 合である.下段のそれは，溶湯の半分が凝固した時点に おける 速度分布である.10A の場合には大きな流動に よつて微細な組織となつているが，2A の場合には流速 はあまり大きくない，その結果，柱状晶の占める割合が 増大して，比較的粗い組織となっている.

Photo. 4 は, Case I , III， VIII， IX の各実験によつて 得られたマクロ組織である. Case III と䜣は，標準試 料とほとんど変わらない組織を示しているが, Case $\mathbb{X}$ では明らかに組織の微細化が認められる. Case 证では, (30)式のような体積力が作用しているが，これは大きな 体積力でないため，ほとんど流動が引き起こされなかつ たものと推察される.また, Case VIII では, Case VI と 同様に，理論解析から推察すると，溶融金属中に 60 サ イクルの微小な振動が生じていることが考兄られるが, この場合にも，採用した実験条件のもとでは流体の微小 振動は凝固組織に影響しなかつたものと推察される。

一方, Case IX の場合には, 印加した磁束と電流の方 向拉よび大きさは，いずれも時間的に変化するが，その 変化には位相差がないため, 誘起される体積力は常に同 じ方向に作用することとなり，Case V の場合と同様 に，比較的大きな体積力が生ずることになる，その結 果, 系内に流動が生じ, 組織が微細化したものと考兄ら れる。

以上, Case $\mathbb{I I} \sim \mathbb{X}$ の結果からも，金属の㠜固現象は, 供給エネルギーや瞬間的な体積力ではなく, 流体運動と それに伴う温度分布によつて支配されるものと推察され る.

\section{5. 結言}

凝固組織の実験結果と理論解析結果に基づいて検討し た結果，次のことがわかつた。

（1）金属の㠜固組織は，直流電流あるいは交流電流 のいずれによつても, 電流密度が高い場合に, 溶融 金属内部に流動が引き起こされて微細化する.

* 境界条件や数值計算法は交献 14）と同し， 


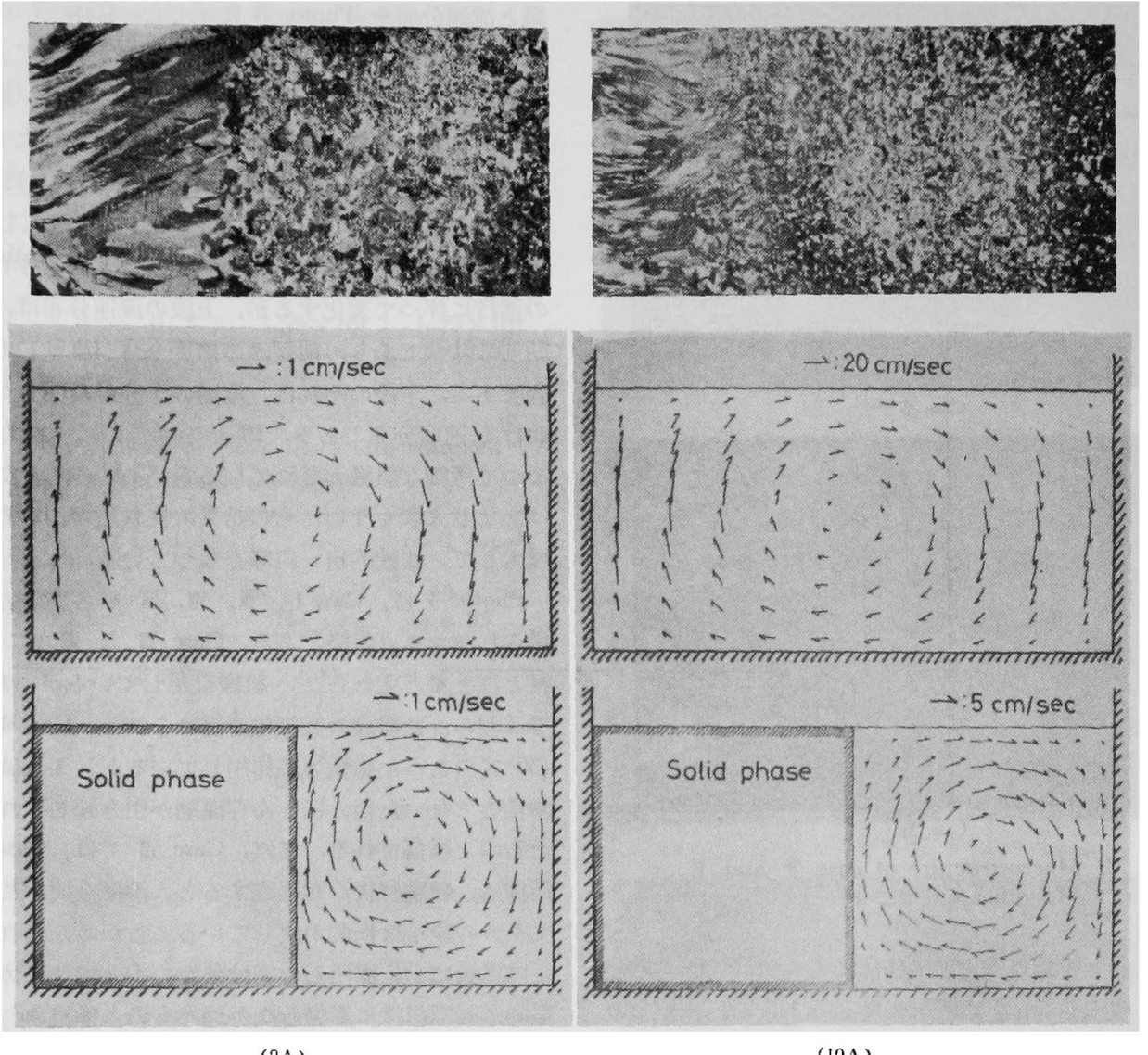

(2A)

(10A)

Photo. 3. Macrostructure and computed velocity profiles of case V. Magnification 0.7 times. (Solid phase means solid fraction $=1$ )

（2）直流磁束だけ，あるいは，直流磁束と交流電流 を併用する場合には，溶融金属内部に生ずる流動を 抑制する電磁気力が働くため，柱状晶がよく発達す る.

（3）直流磁束と交流電流あるいは交流磁束と直流電 流を併用する場合には，理論的には溶融金属内部に 微小振動が生ずるものと考兄られるが，凝固組織に その振動の効果が現われないことから，ここに採用 した実験条件下では金属の㠜固組織は，流体のマク 口な運動とそれに伴つて生ずる温度分不によつて支 配されるものと考えられる。

（4）直流磁束と直流電流，あるいは，交流磁束と交 流電流を併用する場合には，大きな電磁気力が溶融 金属内部に誘起されて，溶融金属が激しく流動寸る ために，組織は大幅に微細化する。

（5）徒来，溶融金属の攪汼法として，移動磁界が用
いられてきたが，新たに凝固組織の微細化括よび治 金反応に有効な覮捧法としては, 直流磁束と直流電 流，あるいは，交流磁束と交流電流を併用する方法 が考えられる。

\section{記号}

a：試料を円筒形とした場合の相当半径,

$$
\text { : 試料厚み }
$$

$b_{1} \cdot b_{2}$ : 矩形試料の長辺と短辺の長さ (m)

B. $B$ : 磁束密度

E : 電界の強さ

F. $F$ : 体積力

H. $H$ : 磁界の強さ $\left(\mathrm{N} \cdot \mathrm{m}^{-3}\right)$

I : 電流

i. $i$ : 電流密度

$$
j \quad: \text { 虚数 }
$$
: 試料長さ, ソレノイドの長さ, 代表長さ

$L \quad$ : インダクタンス 


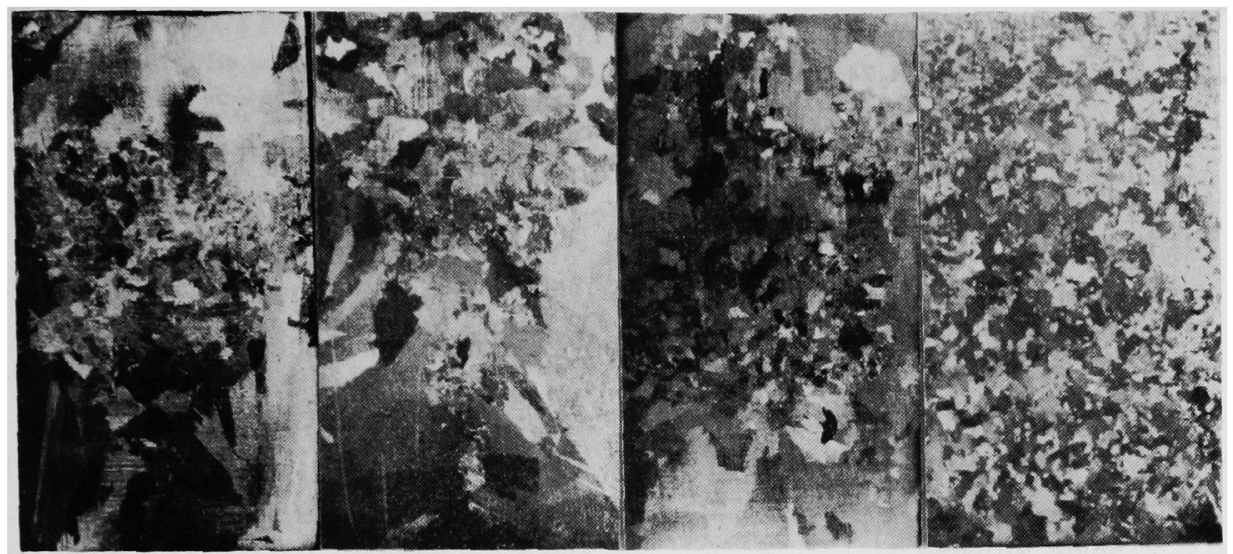

Photo. 4. Macrostructure of case I, VII, VIII and IX. Magnification 0.75 times.

\begin{tabular}{|c|c|c|}
\hline$N$ & : コイルの巻数 & $(-)$ \\
\hline$R$ & : 電気抵㧍 & $(\Omega)$ \\
\hline$S$ & : 試料断面秥 & $\left(\mathrm{m}^{2}\right)$ \\
\hline$t$ & : 時間 & (s) \\
\hline$T$ & : 周期 & (s) \\
\hline$v$ & : 試料体啃 & $\left(\mathrm{m}^{3}\right)$ \\
\hline V. $V$ & : 流速 & $\left(\mathrm{m} \cdot \mathrm{s}^{-1}\right)$ \\
\hline$w$ & : 単位体積当りのエネルギー & $\left(\mathrm{J} \cdot \mathrm{m}^{-3}\right)$ \\
\hline$W$ & :エネルギー & $(\mathrm{J})$ \\
\hline$X$ & : X方向の距離 & $(\mathrm{m})$ \\
\hline$Y$ & : Y方向の距離 & (m) \\
\hline$Z$ & : Z方向の距離 & $(\mathrm{m})$ \\
\hline$\nabla$ & : ナブラ & $\left(m^{-1}\right)$ \\
\hline$\lambda$ & : 長岡係数 & $(-)$ \\
\hline$\mu$ & : 透磁率 & $\left(\mathrm{H} \cdot \mathrm{m}^{-1}\right)$ \\
\hline$\mu_{f}$ & : 流体の粘性 & $\left(\mathrm{kg} \cdot \mathrm{m}^{-1} \cdot \mathrm{s}^{-1}\right)$ \\
\hline$\rho$ & : 密度 & $\left(\mathrm{kg} \cdot \mathrm{m}^{-3}\right)$ \\
\hline$\sigma$ & : 電気伝導度 & $\left(\mathrm{S} \cdot \mathrm{m}^{-1}\right)$ \\
\hline$\omega$ & $\begin{array}{l}\text { : 角速度 } \\
\text { 添 字 }\end{array}$ & $\left(\mathrm{rad} \cdot \mathrm{s}^{-1}\right)$ \\
\hline$m$ & : 体積平均（空間平均） & \\
\hline$X . Y . Z$ & : X. Y Y Z Z のそれぞれのフ & 方向 \\
\hline $\mathrm{O}$ & : 表面 & \\
\hline- & 間平均 & \\
\hline
\end{tabular}

\section{文 献}

1) R. Morando, H. Biloni, G. S. Cole, and $G$. F. Bolling: Met. Trans. 1 (1970), p. 1407

$2)$ ) $D$. U. Uhlmann, T. $P$. Seward, III, and $B$. Chalmers: Trans. Met. Soc. AIME, 236 (1966), p. 527
3) 梅田高照：第 11 回凝固部会提出資料，凝 11- II3 (1975 年 8 月)

4 ) W. C. Johnston, G. R. Kotler, S. O'Hara, $H$. $V$. Ashcom, and $W$. A. Tiller: Trans. Met. Soc. AIME, 233 (1965), p. 1856

5 ) W. C. Johnston, G. R. Kotler, and $W . A$. Tiller: Trans. Met. Soc. AIME, 227 (1963), p. 890

$6) F . G$. Langenberg, $G$. Pestel, and $C . R$. Honeycutt: Trans. Met. Soc. AIME, 221 (1961), p. 993

7 ) A. A. Travaras: Proceeding of the Continuous Casting Symposium of the 102nd AIME Anual Meeting, Chicago, Ill. (1973), p. 197

8 ）佐令木宽太郎，杉谷泰夫，小林純夫, 石村進: シンポジウム予稿“伝熱と対流と偏析”東京. (1977)，P．9[日本金属学会第 IV 総合分科]

9) 田代清, 伊藤幸良, 前出弘文, 風島忠治: シン ポジウム予稿“伝熱々対流と偪析”東京. (1977)， p. 17 [日本金属学会第 $\mathrm{N}$ 総合分科]

10) F. A. Crossley, R. D. Fisher, and $A . G$. Metcalfe: Trans. Met. Soc. AIME., 221 (1961), p. 419

11) G. S. Cole and G. F. Bolling: Trans. Met. Soc. AIME, 236 (1966), p. 1366

12) F. A. Grossley: The Iron Age, 186 (1960) Sep., p. 102

13）桃野 正，玉田真幸，井川克也：鋳物，47 (1975), p. 477

14) J. Szekely, 浅井滋生: 鉄と鋼, 61 (1975), p. 2012 